\title{
The many faces of nodal policing: Team play and improvisation in Dutch community safety
}

\author{
Ronald van Steden \\ $V U$ University \\ Jennifer Wood \\ Temple University
}

\author{
Clifford Shearing \\ University of Cape Town
}

Hans Boutellier

VU University

Verwey-Jonker Institute

Final draft of paper subsequently published as:

Van Steden, R., Wood, J., Shearing, C \& Boutellier, H. 2013. The Many Faces of Nodal Policing: Team Play and Improvisation in Dutch Community Safety. Security Journal [online]: http://dx.doi.org/10.1057/sj.2013.30. 
Abstract: In this paper we reflect on how one police organization, the Dutch police, have acted to embrace nodal assemblages and nodal governance while they have pioneered a form of 'conduit policing' (Shearing, 1999). This strategy, conceived as policing with a 'nodal orientation', combines policing attention on flows of people, information and things through infrastructural nodes with the policing of local communities (Project Group Vision on Policing, 2006). We examine four initiatives of the Dutch police that illustrate different aspects of policing assemblages in Amsterdam. The analysis considers how these nodes have worked to integrate different, but compatible, conceptions of nodal policing.

\section{Introduction}

Since the mid- $20^{\text {th }}$ century police around the world have found themselves faced with what O'Connor dubbed 'the fiscal crises of the state' (1973), and with what Innes (2010) more recently has termed 'an age of austerity'. Within the context of The Netherlands, this does not necessarily mean that the police are low on budget. On the contrary, since 1993, the Dutch police have seen considerable growth in both staffing and expenditure (Haagsma et al, 2012). However, given the constant political and social focus upon safety and security issues (though not necessarily based on 'hard' crime figures) and demands for policing, it is possible to argue that the public police - even with the significant expansion of staff and resources - have been unable to keep pace with the demands they face. Therefore, the Dutch police have reflected on how and where to reduce burdens placed upon them while maintaining appropriate levels of service.

A common response by the Dutch police, and other police forces around the world, has been to develop strategies - resonating with neo-liberal mentalities (Ferguson, 2010; O'Malley and Palmer, 1996) - that seek to enroll others in ways that will assist the police in achieving their security governance objectives by 'lengthening the arm of the law' (Ayling et $a l, 2009)$. These responses have led police organizations to explore ways of engaging in what has been termed 'nodal policing' (Bayley and Shearing, 2001; Wood and Shearing, 2005). In the United Kingdom, for example, the move towards an acceptance of nodal forms of policing - in which police collaborate with others to provide policing services - is reflected in the use of the term 'the policing family' (Johnston, 2005) to signify nodal assemblages that work together, typically with police playing a leadership or 'anchoring' role (Loader and Walker, 2007) to realize their security governance agendas.

In The Netherlands too, we see developments towards nodal forms of policing, often termed 'third-party policing' (Buerger and Mazerolle, 1998) or 'partnership policing' (Wood and Bradley, 2009), which have been actively encouraged by the police. In so doing, the Dutch Police have drawn upon Castells' (1996) conception of networked societies and the idea that within societies 'flows' of people, goods and information often come together at infrastructural nodal points. Castells conceived of these processes as 'spaces of flows', 
including, for example, flows of people and things that go through harbors and airports. The Dutch police have used Castells' ideas to develop the idea of policing with a 'nodal orientation' (Project Group Vision on Policing, 2006). The idea here is that police, and the organizational assemblages that they participate in, should shift their attention towards the managing of national and global nodes at which flows of people, good and things intersect, while continuing their focus on local forms of community-oriented policing.

In this paper we use the metaphor of 'team play', developed by Boutellier and Van Steden (2011), to explore how the Dutch police, within the city of Amsterdam, have sought to realize forms of nodal oriented policing. The 'team play' metaphor refers to the improvisational nature of the thinking and practice that the Dutch police have deployed across a diverse set of policing settings. After sketching the political and societal trends that have sparked the search for nodal forms of policing in The Netherlands, we examine in particular four examples of security governance initiatives: (1) policing through spatial control; (2) policing through coaching; (3) policing through responsive regulation; and (4) policing hot spots and repeat violators. These examples should be considered as archetypal models, since things appear to be 'muddier and messier' (Lindblom, 1959) on the ground. In fact, the models described are, by themselves, products of complex and often ambiguous improvisational processes. Therefore, our goal is not to measure the effectiveness and efficiency of nodal networks, but to explore how 'team play' as a metaphor can help advance our understanding of police efforts to become more agile in addressing contemporary problems of crime and insecurity.

In the course of our analysis we seek to engage in a wider conversation about the faces of nodal policing, not merely in The Netherlands, but in other parts of the globe (Button, 2008), and transnationally (Abrahamsen and Williams, 2011). This conversation centers on questions about the location of police within 'fields' (cf. Moore, 1973) of policing. We argue that the Dutch police are using nodal forms of policing to enable them to create a more rational division of labor within security networks, but also to become more agile as they seek to address a broad range of security concerns. In the final part of our paper we briefly discuss the analogy of 'team play' and improvisation, suggesting an alternative understanding of how power operates in the field of security governance.

\section{Policing under pressure}

The Netherlands has for sometime enjoyed a tradition of 'partnership' policing. Police officers deployed to particular neighborhoods have long sought to encourage the engagement of professionals and citizens as active agents in addressing a variety of local crime and safety issues. For example, the concept of 'neighborhood coordination' (buurtregie), an idea that resonates with established conceptions of community policing, has been a feature of police practice in Amsterdam since the beginning of the new century. The Amsterdam region has been divided, for policing purposes, into 217 neighborhoods, each with its own full-time 
'neighborhood coordinator' (buurtregisseur) - a kind of community policing officer (Van Caem et al, 2013). While these officers are, of course, required to respond to offences they come across in the course of their duties, their primary responsibility is to prevent crime and disorder through engaging those present in their jurisdictions - residents, shopkeepers, pub owners, private security guards, social services, business associations, churches and, (crucially) local government, from the mayor to the street-cleaners - in forward-looking processes intended to anticipate and solve problems. Their focus is on, what Leman-Langlois and Shearing (2004) have termed, 'repairing the future' so as to 'make a better tomorrow' (Froestad, 2013) for their neighborhoods.

Recently this partnership approach to policing has come under considerable pressure as neighborhood coordinators have struggled to meet the high expectations of both citizens and policy-makers to perform a range of roles. As Terpstra (2010, p. 70) puts it:

Often it is hardly realistic that one and the same person can fulfill all these demands: maintaining relations with members of different (ethnic) groups, restoring trust in the police, mediating in conflicts, solving a very wide range of problems of crime and disorder, the enforcement of the rule of law, being approachable for citizens, maintaining the authority of the police at the street level, cooperating with other agencies, offering help and support to people with personal problems, collecting relevant information about public safety problems and meeting organizational performance targets.

In addition, rising crime rates, terrorist attacks, and the public fears that these developments have generated, have fueled concerns that the forms of partnership policing practiced by neighborhood coordinators have been overly tolerant of conflict and violence (see for further discussion, Downes, 1993; Downes and Van Swaaningen, 2007). The concern has been that policing has been too 'soft' in The Netherlands (Das et al, 2007; Punch et al, 2005). Such sentiments have played a part in driving a 'punitive turn' (Pakes, 2005) in the Dutch criminal justice system at the start of the new millennium. This turn has found expression at national government levels in the emergence of a 'tough on crime' stance that has placed a greater emphasis on punishing anti-social behavior, and providing police with more legal tools to enhance their coercive capacities. Politicians have taken their cue from the United States, deploying a rhetoric of 'zero tolerance'. Taken together, political and social developments have led to legal reforms that have authorized, and thereby encouraged, police officers to undertake preventive searches for knives, drugs and other illegal objects on their own initiative and to detain people for relatively minor public nuisance offences.

Also important in shifting practice has been the popularity of New Public Management (NPM) philosophies associated with neo-liberal sensibilities (Osborne and Gaebler, 1992). Within the Dutch police, new systems of performance management sought to establish 
'measurable', quantitative targets, and placed emphasis on output. This, in turn, stimulated the use of fixed penalties and the greater use of arrests by police (Hoogenboezem and Hoogenboezem, 2005). Furthermore, on January $1^{\text {st }} 2013$, the Dutch police completed a move towards centralization, which integrates the former 26 police regions within a single national force. The main assumption driving this centralization process, accompanied by the hardened criminal justice policies over the past decade, has been to improve the effectiveness, efficiency, flexibility and transparency of the Dutch police system.

However, there is little, if any, evidence to suggest that these 'tougher' managerial strategies have improved citizens' trust and confidence in the police. Indeed, research has shown that the general public is less satisfied with this 'harder' instrumental view of policing than they were with the so-called 'softer' forms of policing (Terpstra and Trommel, 2009). Attempts to turn the officers responsible for community-focused forms of policing into 'bandit catchers' (Brogden and Shearing, 1994), and to send policing 'sliding back towards the central-repressive quadrant' (Punch et al, 2008, p. 72), may have reduced the neighborhood coordinators' accessibility in neighborhoods, creating an atmosphere that runs counter to the close relations between them and citizens that was developed in prior years.

The current 'hyperpoliticization' (Van Swaaningen, 2005) of safety and security, however, has not isolated the police from broader networks of agents in the field of security. On the contrary, 'police forces still cooperate in a variety of local networks and work together with all kinds of public and private organizations, in some fields even more intensively than before' (Van Sluis et al, 2008, p. 430). In response to the high demands for safety and security mentioned at the outset, and despite the punitive political turn, the Dutch police have continued to reimagine themselves as a 'new police', with links to other relevant players at local, regional, national and international levels.

In what follows we explore the ways in which police organizations within a Dutch context - in particular the Amsterdam police - have established linkages to private actors, such as commercial security guards and street coaches, as a strategy to enhance the policing resource pool. In particular, we examine the nature of these emerging 'police assemblages' (Brodeur, 2010), the ways in which they have been managed and coordinated, and the logics and associated policing styles that have emerged. Before considering these issues, we lay out the Dutch interpretation of nodal policing, a view that is founded on an understanding that the police are simply one player, albeit an important one (Johnston and Shearing, 2003; Wood and Shearing, 2007), in the field of urban safety.

\section{Policing with a nodal orientation}

Dutch police leaders and policing scholars have been active in assessing the impact of new, and emerging, security threats and their implications for the 'structure of policing' (Bayley and Shearing, 2001). A central challenge posed by these threats relates to the ways in which security issues at the local level are tied to criminal nodes and networks operating nationally 
and transnationally (see also Dupont, 2012). This concern with threats and their challenges were well articulated in the 2006 Dutch report 'Police in Evolution' (Politie in Ontwikkeling):

Because of the significant increase in the mobility of people, goods and information, local, interurban and international safety has become more and more intertwined because open borders, freedom of mobility and computerization offer opportunities not only to entrepreneurs and citizens, but also to criminal individuals, organizations or networks...This has [led to] crime and increasingly international affairs that can no longer be traced back to one single state jurisdiction (Project Group Vision on Policing 2006, p. 21-22).

In response to the fluidity of criminal behavior across space, the Dutch police have, as we noted earlier, chosen to focus much of their gaze on flows of people, goods, money and information that can create opportunities for local breaches of security. These infrastructural nodes, such as airports, seaports, railways, highways and internet servers, constitute crucial sites for police engagement because they provide the infrastructures that enable people, information and commodities to travel across time and space. Policing with a nodal orientation is defined as

... the intensive control and monitoring of infrastructure and the flow of people, goods and money that move along the various forms of this infrastructure. The police act where flows across infrastructures arrive at particular places, such as at the nodes in the infrastructure networks. Each movement of flow and infrastructure requires specific applications for police interventions that fit the characteristics of the particular type of flow or infrastructure (Van Sluis et al, 2011, p. 366).

What this definition implies - as the 2006 Report itself and the practices that have emerged from it make clear - is that for police to achieve this policing mandate, they need to establish collaborative networks. One of the sets of practices, which we explore further below, has been the development of new policing practices to police nodal flows through 'high-tech' applications, which automatically observe and register vehicles moving on ring roads around cities while comparing data found with a wide range of databases (e.g. unpaid fines, known suspects). An example is the control of infrastructural nodes that serve as access or exit points, such as the use of traffic controls on highways. This experimental policing arrangement has allowed the police to compromise people's invisibility and anonymity. Criminals and other unwanted persons can now be identified when entering a local area. In the (near) future, mobile technologies may even allow police to directly alert private security personnel working in businesses to the presence of known shoplifters in the area, which encourages local guards to 'assist' would-be shoplifters to pay for goods. The policing of 
infrastructure thus necessitates the involvement of other players within security nodal networks.

The nodal orientation of the Dutch police described above is an addendum to a more traditional focus on local neighborhoods and communities: it 'combines a perspective on policing in infrastructural networks with one that considers the police a player in... security networks' (Van Sluis et al, 2011, p. 365). This decision to concentrate more closely on 'joined up' (Crawford and Lister, 2004) police work by involving various partners is not new. As early as 1985, the White Paper entitled 'Society and Crime: A Policy Plan for the Future' (Samenleving en criminaliteit: Een beleidsplan voor de komende jaren) clearly foreshadowed that the Dutch police have come to depend heavily on the cooperation of different organizations, both public and private (Punch et al, 2002). The White Paper promoted the 'functional coordination' between state and non-state bodies in the provision of public safety. In the White Paper, neighborhood residents are, among others, conceived of as 'responsible associates' in creating and maintaining a safe and livable social environment. From the early 1990s onwards, 'responsibilization' strategies (Garland, 1996) have been further confirmed by the Dutch government's wider emphasis on 'integral safety', which highlights organizational responses that cut vertically through state agencies and horizontally through non-state sectors to form assemblages of governance. Within such assemblages, flows of power from one node to another are understood as de-centered and multidirectional, rather than as top-down and unidirectional.

This conception of power resonates with both Foucault's (1984/1992) and Latour's (1987) conception of power as having multiple sources - that is, as coming from everywhere. Latour illuminates this conception nicely through his analogy of a rugby game, where the outcome of the game is not determined by who takes, and who accepts or intercepts the first kick, but rather by how the ball moves through the field of action throughout the entire game. The course of the game is shaped by all those who make contact with the ball and all those who influence this. To be a governing node, as Latour's illustration - along with the metaphor of 'team play' - makes clear, an agent (be it a person or an agency), if it is to be able to act as a policing node within a wider network, must be capable of influencing the 'flow of events' (Parker and Braithwaite, 2003) with respect to security. In other words: a governing node must have the capacity 'to regulate self-regulating governance networks by shaping the conditions under which they operate' (Sørenson and Torfing, 2005, p. 202). In seeking to become what might be thought of as a 'nodal police' - an idea that the Victoria Police in Australia referenced through the term 'nexus policing' (Wood, 2006) - the Dutch police have not only continued to act as a crucial node themselves but have, in seeking to foster and steer the direction of nodal assemblages, also emerged as a facilitator of networked forms of policing. 


\section{Four examples}

Keeping in mind the above context, we turn now to four concrete examples of 'team play', which have given life to the Dutch vision of policing with a nodal orientation. We draw these examples from our empirical studies in Amsterdam.

\section{Policing through spatial control}

The first example of policing with a nodal orientation aims to control the open spaces between urban areas and the wider world (Project Group Vision on Policing, 2006; Van Sluis et al, 2011). Over the past few years, the Dutch police have experimented with the installation, and deployment, of 'smart' ring-road cameras and Automatic Number Plate Recognition technologies used to detect and register all vehicles that enter the city. The system checks the vehicle and personal details against various other databases (municipal, police and tax office). This initiative, designed to govern flows of people and goods through space, represents a sophisticated form of 'sorting' and 'gating' that is not dissimilar to the use of, for example, magnetic swipe cards and biometric iris recognition in high security facilities. Via the installation of such technologies across Amsterdam, the Dutch police's objective has been to identify, limit and intercept 'the mobility of "evil"' (Project Group Vision on Policing, 2006, p. 78) by using visual recording equipment - mostly CCTV cameras - to undermine the anonymity and invisibility of known suspects.

The interaction between these technologies and neighborhood coordinators is purported to enhance the Dutch emphasis on local communities by using information technology to inform coordinators of threats, like suspicious vehicles and people entering the city. Following the 2006 Report,

... the notion 'from your local neighborhood to the world at large' means in particular that there is a relationship between the different levels on which safety can be organized. For individual police officers and for the police as an organization this means in practice that whenever there are national objectives (e.g. fighting terrorism), local activities are expressly placed in the context of these broader safety objectives (Project Group Vision on Policing, 2006, p. 21-22).

As such, the Dutch police emphasize that there should be clarity between various partners about their perceptions of threats and their respective responsibilities in improving public safety and security. In line with the examples noted above, the police utilize mobile technologies to inform citizens and other stakeholders of information gathered by sending text messages, through an initiative called SMS-alert (Korteland and Bekkers, 2007). The intention is to enroll third parties, as co-producers of community safety, to engage with the police, in the recognition, anticipation and prevention of local crime and disorder. This constitutes an innovative program that seeks to promote the process of 'knowing and being 
known', and which involves the police entering into relationships with citizens and organizations - both public and private - for the purpose of exchanging information (Ericson and Haggerty, 1997; Ayling et al, 2009). Community safety programs thereby integrate with national and even global or transnational levels of policing with a strong emphasis on prevention.

\section{Policing through coaching}

The second example we will consider is the deployment of 'street coaches' who engage with disorderly youngsters on the streets of Amsterdam. These coaches, provided by a commercial security firm and employed by a private foundation - a civil society entity - under contract with the city council, have been conceived of as 'filling the gap' between reactive policing strategies and preventive youth care. The central idea underlying this initiative was to bring together the worlds of policing and community-based care in an effort to reduce the problem of youth 'hanging around' (Van Steden and Jones, 2008). Street coaches work in conjunction with 'home helpers' (private social workers directly working for the foundation) who visit the parents of youngsters in trouble. The coaches, who have no judicial and related powers (e.g. they may not issue fines), cycle through Amsterdam neighborhoods and boroughs to reduce the extent to which youth engage in activities that constitute a 'nuisance'.

One strategy that both street coaches and home helpers employ is to activate (problematic) youth and their parents, as local regulators, through signed agreements, to commit to reforming their behaviors. A consequence of these agreements is that parents are made more aware of their children's misconduct and are encouraged, as parents, to play a greater supervisory role of their children. This use of self-regulation within communities has a long history and is found in a variety of guises in different places across the globe (see, for example, Froestad, 2013). In addition to providing a visible presence on the streets of Amsterdam, coaches and helpers guide troublesome youth through a range of complex, and sometimes contradictory, set of bureaucratic services and regulatory provisions. The hope has been that this initiative would streamline multifarious youth programs into a more integrated, simpler and efficient set of processes.

As the daily work of street coaches illuminates, 'capable guardians' (Cohen and Felson, 1979) in local neighborhoods are not necessarily police. In this instance, although police officers are involved in the wider security network as neighborhood coordinators, they tend to remain in the background. They see their role less as offering services directly, and more as guarantors of order who act to ensure that networks of capable guardians exist and are operating to promote safety (see also Wood and Marks, 2007). Their role is primarily to provide informational support for the coaches and helpers by providing back-up support in cases where the unique legal authority and coercive capacity of the police is required (see Shearing and Leon, 1976). Particularly noteworthy in the case of street coaches is the fact that the vast bulk of the infrastructure is provided by a private foundation. Street coaches thus act 
'in the shadow of the law' (Mnookin and Kornhauser, 1979), meaning that they maintain public order on behalf of government agencies that remain in the background, but that are ultimately in control.

\section{Policing through responsive regulation}

Our third example is that of the Flying Squads (Vliegende Brigades) that are routinely deployed across Amsterdam (De Groot and Van Steden, 2011; Van Steden and Stekelenburg, 2010). Flying Squads are made up of police, health care service officials, and social workers under the political authority of the municipal enforcement department. As a component of Flying Squads, municipal enforcement officers (see below) work under the operational direction of police officers, most notably neighborhood coordinators. Municipal responsibilities within this policing arrangement originated as an initiative designed primarily to address long-term unemployment in 1989. Lacking any police powers, city wardens (stadswachten) were deployed to perform a security governance function through their visible presence as agents and via the provision of information to tourists and residents in Dutch cities (Hauber et al, 1996). Again, schemes such as this can be found in different incarnations elsewhere, for instance, the use of downtown ambassadors in the United States, Canada and Australia (Sleiman and Lippert, 2010). In The Netherlands, the national government has sought to professionalize city wardens over the past few years. They are now regarded as 'municipal enforcement officers', as professional order maintenance personnel holding limited police powers.

Flying Squads embody flexible teams that, akin to street coaches and home helpers, are intended to act to reduce nuisance behavior. Within these Squads, municipal enforcement officers are uniformed officials who posses powers that enable them to issue on-the-spot penalties for anti-social conduct, such as public urination, public drunkenness and intoxication. Some of these officers carry handcuffs, though their coercive powers are more limited than those of Dutch police officers. Municipal enforcement officers, like the Police Community Support Officers (PCSOs) in Britain, provide a second tier of 'police' who are appointed to undertake street patrols and apply a problem-solving approach to crime and disorder (Johnston, 2005). Unlike PCSOs, Dutch municipal enforcement officers are employed by local government, not by a police authority. Their work can nevertheless be situated in debates about 'security governance' (Johnston and Shearing, 2003) and the 'pluralization' or 'multilateralization' (Bayley and Shearing, 2001) of policing, referring to the rise of visible (quasi-)policing professionals alongside the blue-colored state police.

The emergence of Flying Squads must be interpreted against the background of widespread unease about low-level, but annoying, disturbances like public drunkenness, drug abuse and panhandling in Amsterdam. Two important policy objectives of Flying Brigades are (a) to tackle problems caused by, among others, (homeless) drug addicts through imposing fixed penalties upon them, and (b) to offer vulnerable people personal and medical care if 
necessary. These goals translate into combining strategies of care with harder edged policing tactics to provide both 'carrots' and 'sticks' models (cf. Ayres and Braithwaite, 1992). By using the 'soft power' of social workers who work to convince people like drug addicts to visit doctors or a rehabilitation center, the Squad typically initiates its interventions at the base of the enforcement pyramid. If a gentle approach - what Braithwaite (1997) terms 'speaking softly' - fails, then municipal enforcement officers, who carry a 'small stick' in the form of the ability to impose fines, are able to escalate matters up the pyramid. In the course of taking these various actions, the Squad is able to build up dossiers outlining their lower-level actions, which enable them to escalate matters to the top of the pyramid by eventually mobilizing the police officers within the Squad, who have the power to arrest offenders - Braithwaite's 'big stick'.

\section{Policing hot spots and repeat violators}

Our fourth and final example is a neighborhood safety team (buurtveiligheidsteam) program in Amsterdam. A major principle of this program is that both the police and the municipality invest in a targeted approach to public disorder in local urban areas. Although the municipal enforcement department is in political control, as with the previous examples, police are recognized as the team leader. A neighborhood coordinator, who is assisted by a police colleague and two municipal enforcement officers, form a team. Depending on the issues being addressed, teams are supplemented by others, such as private security guards, street coaches, caretakers, and youth workers. Since February 2008, when the program was initiated, four teams have been active in the northern and eastern parts of Amsterdam. Their purpose has been to improve the 'quality of life' in appointed neighborhoods by addressing (minor) safety problems such as litter, illegal parking and troublesome youth.

The most striking element of the teams' working method is that residents have a direct say by identifying 'hot spots' and other pressing local disorder problems. On account of people's complaints and concerns about public nuisance and antisocial behavior, professionals adopt a focused policy on the most 'prominent' people (notorious lawbreakers) and places (such as disorderly squares and drug scenes) in town (Van Stokkom, 2013). This policy has been inspired by British experiments with 'reassurance policing' (Innes, 2004) and expresses the business principles of Intelligence-Led Policing by focusing resources on the most harmful people and places (Ratcliffe, 2008). As part of the processes initiated by the teams, neighborhood coordinators frequently set up interactive gatherings of citizens, drawn from a mixture of community groups, to promote dialogue, active listening and feedback about pressing safety issues. In addition to formal gatherings, neighborhood coordinators also organize other channels of communication, such as surveys and e-mail exchanges. The gatherings between professionals and citizens approximate the 'beat meetings' Skogan (2006) studied in Chicago. 


\section{Improvisation}

Our purpose so far has not been evaluative, but rather suggestive of the agility and nodal imagination of the Dutch Police in larger 'teams' of security governance players. In the above examples, we hope to have made clear the fact that the Dutch police are now routinely positioned within assemblages of resources to collectively address security issues. Our examples reveal that such network engagement can, and does, take place, with the police neighborhood coordinators in particular - mostly playing a central role. At the same time, however, the municipality of Amsterdam also takes up a pivotal position in shaping team play. Team leaders vary, depending on the problem at hand, and the logic deployed to address it. Due to this morphing character, the position of police within security networks is sometimes stable, but often it is not.

The challenge for nodes, including the police and municipal agencies, has therefore been to determine which assemblages work best for different types of problems. Depending on the nature of the problem, questions arise as to who should take which positions within a policing field, and what the rules of the game should be (Ayling et al, 2009). The Dutch police have begun to consider these issues, but to date have done so in a rather improvised fashion in which the enrollment and alignment of third parties are central features of community safety (Boutellier, forthcoming). Nodal team work, much similar to the improvisations of a jazz ensemble,

... emerges as an important medium for exhibiting as well as a means of conceiving and (re)enacting interpersonal relationships. It derives particularly 'from the force of the context, one that challenges players, listeners and all those caught up in its social field, to reevaluate the "space" in which the conjoined activities of making music and community happen' (Fischlin cited in Cobussen, 2008, p. 54).

As we alluded to earlier, such experiments have been happening simultaneously, and in parallel with the move to introduce tougher forms of policing. In practice, as Ayres and Braithwaite's (1992) picture of a regulatory pyramid shows, governance arrangements function as a sort of incremental 'regulatory pyramid'. This pyramid is most obvious in the case of the Flying Squads, but lies concealed in the other examples too. Coercive measures of law enforcement are merely seen as an ultimum remedium, as a last straw. If citizens, social workers, home helpers, street coaches, municipal law enforcement officers and other partners in community safety fail to solve problems and restore public order, the police can be brought into action (Boutellier and Van Steden, 2011). Neighborhood coordinators and other police colleagues are, at any moment, capable of intervening when escalation up the pyramid is required.

The above examples suggest that although the Dutch police are certainly being encouraged to make greater use of their 'big stick', this has not meant that neighborhood 
coordinators are not continuing to be very active at the bottom end of the regulatory pyramid where they, and the policing assemblages they are a part of, speak much more softly. The police are essential players because of their big sticks, but oftentimes, these can be subordinated to softer tools used by other nodal players. Within nodal networks, police officers, like the neighborhood coordinators we considered, act in ways that fully recognize that 'what works' (hard and soft) depends on the situation.

\section{Conclusions}

A vital development within the governance of security has been the mobilization of resources outside of state bureaucracies in the pursuit of safety and security. This is a strategy that citizens, corporations and non-profit organizations have used to create nodal assemblages that stretch beyond states' resources and capacities. The Dutch government generally, and the Dutch police specifically, have actively designed and implemented policies to identify, enhance, mobilize and integrate a wide variety of capacities - both local and national - in pursuing their security governance agendas. In considering how this has been done, our examples show that the emergence of the nodal assemblages that now define Dutch policing evolved through a number of innovative and opportunistic processes that have, and are continuing to, profoundly reshaped policing and police work. We have argued, via an analysis of actions taken by the police in Amsterdam, that a variety of different developments, which share a distinct 'family resemblance' (Wittgenstein, 1953/2001) are collectively reshaping Dutch policing by moving it in a nodal direction.

In summary, policing operates in many forms, with different entities taking up various positions in the field of action in which security nodes operate. As we have seen in the case of neighborhood coordinators, the police may play a central role in managing assemblages. In such instances they act as a coordinating hub that determines what security capacities exist within a policing field and decides 'who should do what' to reduce crime and disorder. The nodal assemblages that are emerging within the Netherlands and elsewhere have experienced, and continue to present, difficult challenges with respect to coordination. Our examples illustrate that these challenges are being explored through the innovative and experimental processes. In the developments taking place, what we are witnessing is the Dutch police playing an active role in the shaping, but not controlling of the emergence of nodal security arrangements in the Netherlands. In our case illustrations we have confirmed that power, as Foucault and Latour have advised, operates both horizontally and vertically. Through their security assemblages, the police may govern us more indirectly (although perhaps no less effectively) than ever before. 


\section{References}

Abrahamsen, R. and Williams, M.C. (2011) Security beyond the State: Private Security in International Politics. Cambridge: Cambridge University Press.

Ayling, J. Grabosky, P. and Shearing, C. (2009) Lengthening the Arm of the Law: Enhancing Police Resources in the Twenty-First Century. Cambridge: Cambridge University Press.

Ayres, I. and Braithwaite, J. (1992) Responsive Regulation: Transcending the Deregulation Debate. Oxford: Oxford University Press.

Bayley, D.H. and Shearing, C.D. (2001) The New Structure of Policing: Description, Conceptualization, and Research Agenda. Washington D.C.: National Institute of Justice.

Boutellier, H. (forthcoming) The Improvising Society: On Social Order in a Limitless World. The Hague: Eleven.

Boutellier, H. and Van Steden, R. (2011) Governing Nodal Governance: The "Anchoring" of Local Security Networks. In: A. Crawford (ed.) International and Comparative Criminal Justice and Urban Governance: Convergences and Divergences in Global, National and Local Settings. Cambridge: Cambridge University Press, pp. 461-482.

Braithwaite, J. (1997) On Speaking Softly and Carrying Big Sticks: Neglected Dimensions of a Republication Separation of Powers. University of Toronto Law Journal 47: 305-361.

Brodeur, J.P. (2010) The Policing Web. Oxford: Oxford University Press.

Brogden, M. and Shearing, C. (1994) Policing for a New South Africa. London and New York: Routledge. 
Buerger, M. and Mazerolle, L. (1998) Third Party Policing: A Theoretical Analysis of an Emerging Trend. Justice Quarterly 15(2): 301-328.

Button, M. (2008) Doing Security: Critical Reflections and an Agenda for Change. Houndmills: Palgrave Macmillan.

Castells, M. (1996) The Rise of the Network Society: The Information Age: Economy, Society and Culture. Cambridge: Blackwell.

Cobussen, M. (2008) Improvisation: Between the Musical and the Social. Dutch Journal of Music Theory 13(1): 48-55.

Cohen, L.E. and Felson, M. (1979) Social Change and Crime Rate Trends: A Routine Activity Approach. American Sociological Review 44(4): 588-608.

Crawford, A. and Lister, S. (2004) The Patchwork Shape of Reassurance Policing in England and Wales: Integrated Local Security Quilts or Frayed, Fragmented and Fragile Tangled Webs? Policing: An International Journal of Police Strategies and Management 27(3): 413430.

Das, D., Huberts, L. and Van Steden, R. (2007) The Changing "Soul" of Dutch Policing: Responses to New Security Demands and the Relationship with Dutch Tradition. Policing: An International Journal of Police Strategies \& Management 30(3): 518-532.

De Groot, I. and Van Steden, R. (2011) De Praktijk van Vliegende Brigades: Doelen, Werkprocessen en Opbrengsten [The Practice of Flying Squads: Goals, Processes and Outputs]. Amsterdam/Den Haag: Vrije Universiteit/Nicis Institute.

Downes, D. (1993) Contrasts in Tolerance: Post-war Penal Policy in the Netherlands and England and Wales. Oxford: Oxford University Press.

Downes, D. and Van Swaaningen, R. (2007) The Road to Dystopia? Changes in the Penal Climate of the Netherlands. Crime and Justice 35(1): 31-71.

Dupont, B. (2012) The Cyber Security Environment to 2022: Trends, Drivers and Implications. Prepared for the National Cyber Security Directorate. Public Safety. Canada. Available online at http://papers.ssrn.com/sol3/papers.cfm?abstract id=2208548 (accessed 11 March 2013). 
Ericson, R. and Haggerty, K. (1997) Policing the Risk Society. Oxford: Clarendon Press.

Ferguson, J. (2010) The Uses of Neoliberalism. Antipode 41(1): 166-184.

Foucault, M. (1984/1992) The Use of Pleasure: The History of Sexuality (Translated from the French by Robert Hurley). London: Penguin.

Froestad, J. (2013) Security Governance, Policing, and Local Capacity. Advances in Policing. In: J. Froestad with C. Shearing (eds.) Theory and Practice Series. Boca Raton, FL: CRC Press.

Garland, D. (1996) 'The Limits of the Sovereign State: Strategies of Crime Control in Contemporary Society'. The British Journal of Criminology, 36 (4), 445-471.

Haagsma, J., Rümke, T., Smits, I., Van der Veen, E. and Wiebrens, C. (2012) De Sterke Arm: Feiten and Mythes [The Strong Arm of the Law: Facts and Myths]. Amsterdam: Reed Business (Commissie Politie en Wetenschap).

Hauber, A., Hofstra, B., Toornvliet, L. and Zandbergen, A. (1996) Some New Forms of Functional Social Control in the Netherlands and their Effects. British Journal of Criminology 36(2): 199-219.

Hoogenboezem, J. and Hoogenboezem, D. (2005) Coping with Targets: Performance Measurement in the Netherlands Police. International Journal of Productivity and Performance Management 54(7): 568-578.

Innes, M. (2004) Reinventing Tradition? Reassurance, Neighbourhood Security and Policing. Criminology and Criminal Justice 4(2): 151-171.

Innes, M. (2010) A "Mirror" and a "Motor": Researching and Reforming Policing in an Age of Austerity. Policing: A Journal of Policy and Practice 4(2): 127-134.

Johnston, L. (2005) From "Community" to "Neighbourhood" Policing: Police Community Support Officers and the "Police Extended Family" in London. Journal of Community \& Applied Social Psychology 15(3): 241-254.

Johnston, L. and Shearing, C. (2003) Governing Security: Explorations in Policing and Justice. London: Routledge. 
Korteland, E. and Bekkers, V. (2007) Diffusion of E-Government Innovations in the Dutch Public Sector: The Case of Digital Community Policing. Electronic Government 4656: 252264.

Latour, B. (1987) Science in Action: How to Follow Scientists and Engineers through Society. Cambridge, MA: Harvard University Press.

Leman-Langlois, S. and Shearing, C. (2004) Repairing the Future: The South African Truth and Reconciliation Commission at Work. In: G. Gilligan and J. Pratt (eds.) Crime, Truth and Justice: Official Enquiry, Discourse, Knowledge. Cullompton: Willan, pp. 222-242.

Lindblom, C. (1959) The Science of Muddling Through. Public Administration 19(2): 79-88.

Loader, I. and Walker, N. (2007) Civilizing Security. Cambridge: Cambridge University Press.

Mnoonkin, R. and Kornhauser, L. (1979) Bargaining in the Shadow of the Law: The Case of Divorce. The Yale Law Journal 88(5): 950-997.

Moore, S.F. (1973) The Semi-Autonomous Social Field as an Appropriate Subject of Study. Law \& Society Review 7(4): 719-746.

Ministry of Justice. (1985) Samenleving en criminaliteit: Een beleidsplan voor de komende jaren [Society and Crime: A Policy Plan for the Future] (Tweede Kamer, vergaderjaar 198485,18995 , nos. 1, 2).

Netherlands Project Group Vision on Policing. (2006) The Police in Evolution: Vision on Policing. The Hague: Netherlands Project Group Vision on Policing.

O’Connor, J. (1973) The Fiscal Crisis of the State. New York: St. Martin's Press.

O’Malley, P. and Palmer, D. (1996) Post-Keynesian Policing. Economy and Society 25(2): 137-155.

Osborne, D. and Gaebler, T. (1992) Reinventing Government: How the Entrepreneurial Spirit is Transforming the Public Sector. Reading: Addison-Wesley.

Pakes, F. (2005) Penalization and Retreat: The Changing Face of Dutch Criminal Justice. Criminal Justice 5(2): 145-161. 
Parker, C. and Braithwaite, J. (2003) Regulation. In: P. Cane and M. Tushnet (eds.) Handbook of Legal Studies. Oxford: Oxford University Press, pp. 119-145.

Punch, M., Van der Vijver, K. and Zoomer, O. (2002) Dutch "COP": Developing Community-Policing in The Netherlands. Policing: A Journal of Policy and Practice 25(1): $60-79$.

Punch, M., Hoogenboom, B. and Williamson, T. (2005) Paradigm Lost: The Dutch Dilemma. Australian \& New Zealand Journal of Criminology 38(2): 268-281.

Punch, M., Hoogenboom, B. and Van der Vijver, K. (2008) Community Policing in the Netherlands: Four Generations of Redefinition. In: T. Williamson (ed.) The Handbook of Knowledge-Based Policing: Current Conceptions and Future Directions. Chichester: Wiley, pp. 59-78.

Ratcliffe, J.H. (2008) Intelligence-Led Policing. Cullompton: Willan.

Shearing, C. (1999) Remarks of Professor Shearing [On Zero Tolerance Policing]. Criminal Law Bulletin 35(4): 378-83.

Shearing, C. and Leon, S.J. (1976) Reconsidering the Police Role: a Challenge to a Challenge of a Popular Conception. Canadian Journal of Criminology and Corrections 19(4): 331-345.

Skogan, W.G. (2006) Police and Community Policing in Chicago: A Tale of Three Cities. Oxford: Oxford University Press.

Sleiman, M. and Lippert, R. (2010) Downtown Ambassadors, Police Relations and "Clean and Safe" Security. Policing and Society 20(3): 316-335.

Sørenson, E. and Torfing, J. (2005) The Democratic Anchorage of Governance Networks. Scandinavian Political Studies 28(3): 195-218.

Terpstra, J. (2010) Community Policing in the Netherlands: Ambitions and Realization. Policing: A Journal of Policy and Practice 4(1): 64-72.

Terpstra, J. and Trommel, W. (2009) Police, Managerialization and Presentational Strategies. Policing: An International Journal of Police Strategies and Management 31(1): 128-143. 
Van Caem, B., Van Steden, R., Boutellier, H. and Van Stokkom, B. (2013) Community Policing "Light": On Proximity and Distance in the Relationship between Neighborhood Coordinators and Citizens. Policing: A Journal of Policy and Practice, in press.

Van Sluis, A., Marks, P. and Bekkers, V. (2011) Nodal Policing in the Netherlands: Strategic and Normative Considerations on an Evolving Practice. Policing: A Journal of Policy and Practice 5(4): 365-371.

Van Sluis, A., Cachet, L. and Ringeling, A. (2008) Result-Based Agreements for the Police in the Netherlands. Policing: An International Journal of Police Strategies \& Management 31(3): 415-434.

Van Steden, R. and Jones, T. (2008) Straatcoaches in Slotervaart: Enige Kanttekeningen bij het Idee van een "Overheid op Afstand" [Streetcoaches in Slotervaart: Some Comments on the Idea of a 'Government-at-a-Distance']. Tijdschrift voor Veiligheid 7(4): 20-29.

Van Steden, R. and Stekelenburg, S. (2010) Vliegende Brigades in Amsterdam: Een Bestuurlijke Aanpak van Overlastgevend Gedrag [Flying Squads in Amsterdam: An Administrative Approach to Nuisance]. In: W. Duijst, J. Terpstra, D. van Toor and L. Gunther Moor (eds.) Aanpakken van overlast. Dordrecht: SMVP, pp. 135-144.

Van Stokkom, B. (2013) Frontlijnwerk met Potentie: Buurtveiligheidsteams in Amsterdam [Frontline Work with Potential: Safer Neighborhood Teams in Amsterdam]. The Hague: Boom-Lemma.

Van Swaaningen, R. (2005) Public Safety and the Management of Fear. Theoretical Criminology 9(3): 289-305.

Wittgenstein, L. (1953/2001). Philosophical Investigations. Oxford: Blackwell.

Wood J. (2006) Mapping Security Governance: The Nexus Policing Project in Victoria, Australia. Paper presented at the annual meeting of the American Society of Criminology; November 12-15, St Louis, Missouri.

Wood, J. and Bradley, D. (2009) Embedding Partnership Policing: What We've Learned from the Nexus Policing Project. Police Practice and Research 10(2): 133-144. 
Wood, J. and Marks, M. (2007) Cultural Change through 'Nexus Policing'. In: M. O’Neill, M. Marks and A.M. Singh (eds.) Police Occupational Culture: New Debates and Directions. Amsterdam: Elsevier, pp. 275-294.

Wood, J. and Shearing, C. (2005) Nodal Governance, Denizenship and Communal Space: Challenging the Westphalian Ideal. In: S. Robins (ed.) Limits to Liberation: Culture, Citizenship and Governance after Apartheid. Oxford: James Currey Press, pp. 97-112.

Wood, J. and Shearing, C. (2007) Imagining Security. Cullompton: Willan. 